\title{
Experimental Study on Shear Behavior of Reinforced Concrete Sandwich Deep Beam
}

\author{
Vaka Gopi $^{1 *}$, Kagita Kumara Swamy ${ }^{1}$, Arepalli Peda Gopi ${ }^{2}$, Vejendla Lakshman Narayana ${ }^{2}$ \\ ${ }^{1}$ Department of Civil Engineering, Usha Rama College of Engineering and Technology, Vijayawada 521109, Andhra Pradesh, \\ India \\ ${ }^{2}$ Vignan's Nirula Institute of Technology \& Science for Women, Peda Palakaluru, Guntur 522009, Andhra Pradesh, India
}

Corresponding Author Email: vakagopi777@gmail.com

https://doi.org/10.18280/acsm.440501

Received: 6 April 2020

Accepted: 11 September 2020

\section{Keywords:}

deep beam, shear reinforcement, insulation pad, crack pattern, diagonal crack

\begin{abstract}
In present making of construction industry at a high pace. The tendency of world influenced the high raised buildings. In modern days one of the most common element is deep beam, constructed a small span to depth ratio. The transfer girders most of used in deep beams. In an experimental program consists of 12 deep beam specimens are carried out for shear strength behavior investigation of Reinforced Concrete sandwich deep beam concealed with insulation pad in various depths $200 \mathrm{~mm}$ and $300 \mathrm{~mm}$ and $400 \mathrm{~mm}$. in the experimental program effective length, depth, the width of the specimens, width of bearing plates, longitudinal reinforcement as $1 \%$ to maintain constantly and horizontal reinforcement as varies as $0.15 \%$ and $0.25 \%$ and $0.35 \%$. We are considered shear span to depth ratio of deep beam is 0.95 . The main aim of the experimental study the influence of longitudinal shear reinforcement along with vertical and horizontal shear reinforcement on the shear strength, shear ductility of RC sandwich deep beams of insulation pads placed at different depths.
\end{abstract}

\section{INTRODUCTION}

Deep beams are simple beams and load carrying to structural elements. In which major amount of load will be carried to the supports of deep beams by a compressive force combining the load and the reaction beam. Consequently, the strain distribution is never again thought to be direct, and the shear mishappening wind up unique when contrasted with pure flexure. Reinforced concrete deep beams have helpful applications in tall structures, seaward structures, and establishments. Especially the utilization of profound shafts at the lower levels in tall structures for private and business purposes has expanded quickly in view of their accommodation and economic proficiency. Based on some experimental results variation of width of deep beam it doesn't affect the shear strength of specimen because of this only in my present study we are varying the depth of polystyrene (200, $300,400 \mathrm{~mm}$ ) in middle portion of the deep beam and the observe the shear strength behavior, then compare the experimental results with control specimens.

To increase the height of the deep beam by reduction of shear strength. And also, web reinforcement also plays a main role in size effect of deep beam [1]. In strut and tie modal, size of shear strength reinforced concrete deep beam expression used [2]. Along udl and concentrated loads on deep beam we understand the horizontal reinforcement distribution along the size of the deep beam influence the mode of failure sudden flexural to diagonal shear failure [3]. According to base on shear transfer mechanism to develop the shear strength expression of deep beam through find the strut - tie model [4]. For both strut boundary and strut geometry play an important role in controlling size effect [5]. Prove that variation of a/dratio, will effect on shear strength of deep beam under failure load [6]. Discussion about the increases the shear strength of deep beam with alternative web reinforcement with different percentages [7].

\section{DETAILS OF BEAM REINFORCEMENT}

The extension otherwise bent up the flexural reinforcement beyond the support reactions as to achieve the strut and tie action to provide adequate anchorage in deep beam. (The mix design of Deep beam shown in Table 1). As per IS 456-2000 [8] the minimum shear [9] reinforcement will be taken in in horizontal and vertical shear reinforcement is $0.15 \%, 0.25 \%$, and $0.35 \%$. The spacing of $8 \mathrm{~mm}$ diameter vertical and horizontal stirrups for the above minimum vertical and horizontal shear reinforcement was $575 \mathrm{~mm}, 285 \mathrm{~mm}$, and $180 \mathrm{~mm}$ and $275 \mathrm{~mm}, 135 \mathrm{~mm}, 90 \mathrm{~mm}$ center-to-center as shown in Table 2.

Table 1. Summary of concrete mix design

\begin{tabular}{cc}
\hline Description & Type \\
\hline Cement type & OPC 53 grade \\
& Crushed granite and natural washed \\
Aggregate type & sand \\
Fine aggregate content & $710 \mathrm{~kg} / \mathrm{m}^{3}$ \\
Cement content & $420 \mathrm{~kg} / \mathrm{m}^{3}$ \\
Coarse aggregate & $1127 \mathrm{~kg} / \mathrm{m}^{3}$ \\
content & $100 \mathrm{~mm}$ \\
Slump for concrete & 0.45 \\
Water/cement ratio & \\
\hline
\end{tabular}




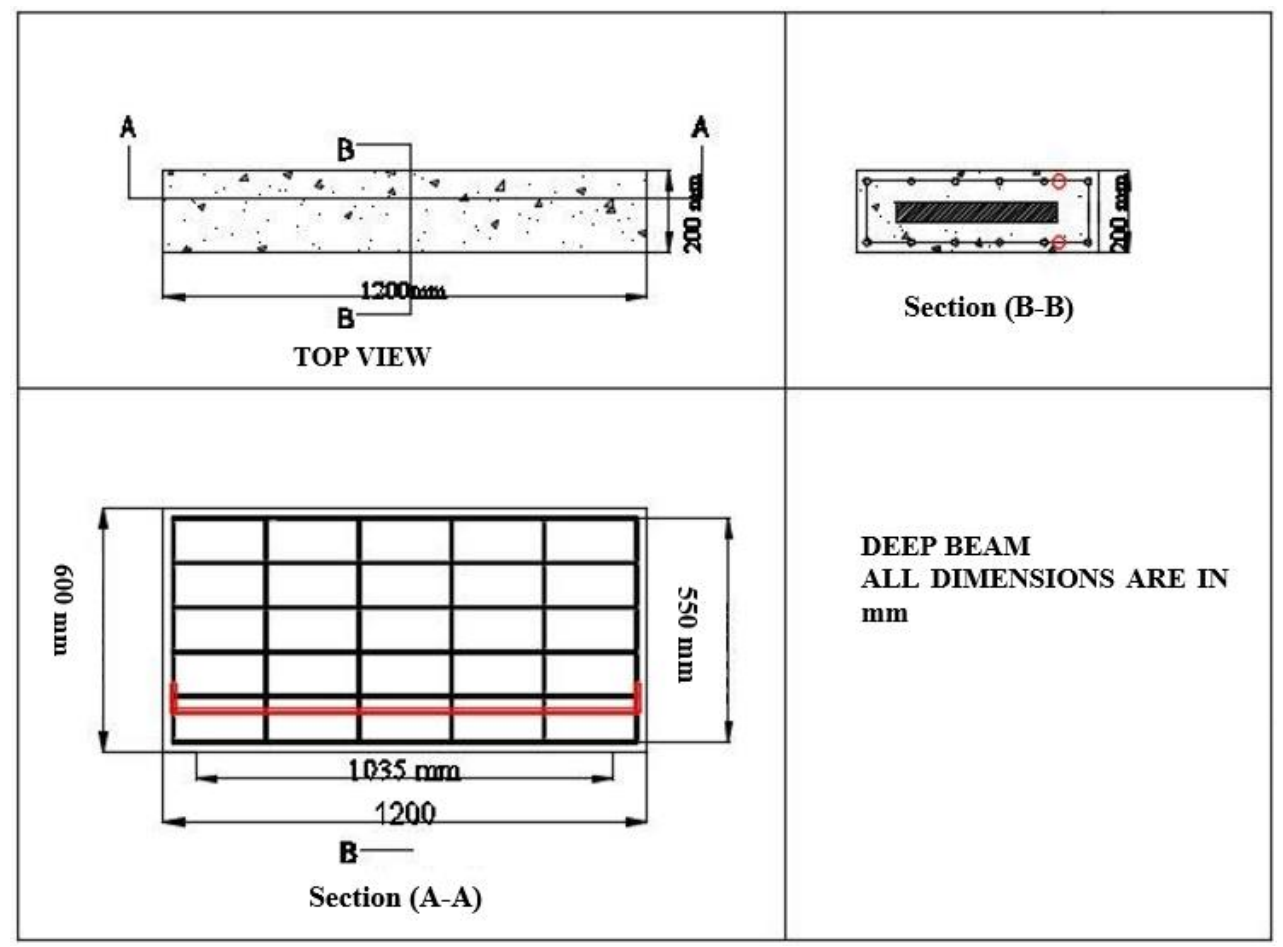

Figure 1. Plan, elevation of sandwich deep beam

The shear reinforcement of deep beam in vertical and horizontal $0.12 \%$ and 0.2 of $\mathrm{c} / \mathrm{s}$ using HYSD bars. The percentage of vertical and horizontal reinforcement with addition to the $200 \mathrm{~mm}, 300 \mathrm{~mm}, 400 \mathrm{~mm}$ polystyrene depths of deep beam. Three percentages $0.15 \%, 0.25 \%, 0.35 \%$ shear reinforcement percentages in horizontal and vertical direction applied. To study the shear strength and crack behavior of the deep beam. And another form of varying vertical and horizontal shear reinforcement percent $(0.15 \%, 0.25 \%$ and $0.35 \%)$ in the web [10] was used. The reinforcement details of shear reinforcement percent $(0.15 \%, 0.25 \%$ and $0.35 \%)$ is shown in Figure 2 to Figure 13.

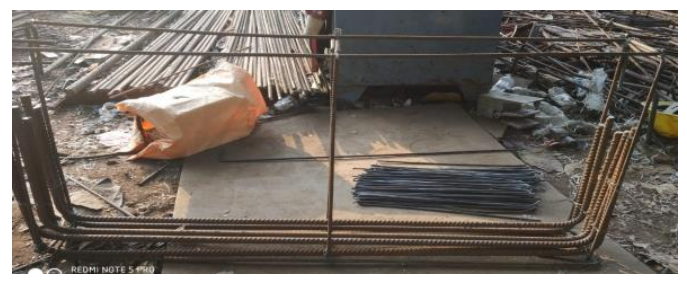

Figure 2. Reinforcement details of $0.15 \%$ control deep beam

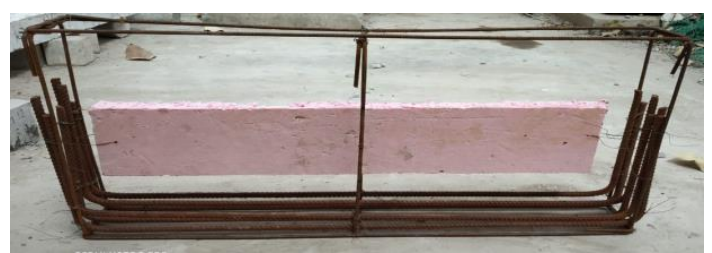

Figure 3. Reinforcement details of $0.15 \%-200 \mathrm{~mm}$ deep beam

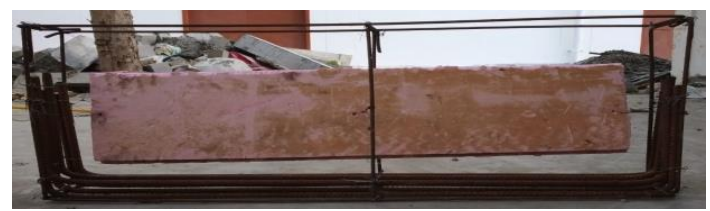

Figure 4. Reinforcement details of 0.15\%-300mm deep beam

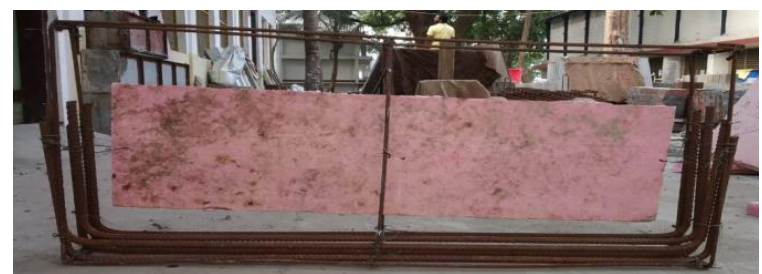

Figure 5. Reinforcement details of $0.15 \%-400 \mathrm{~mm}$ deep beam

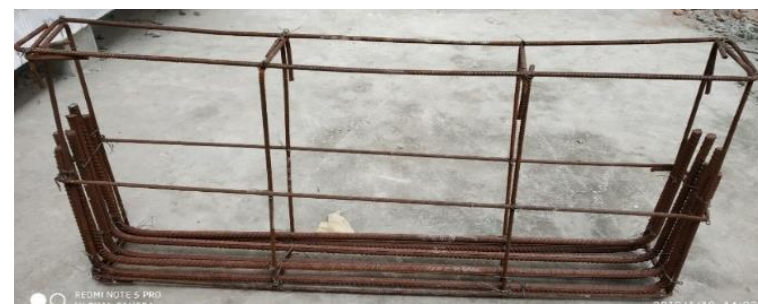

Figure 6. Reinforcement details of $0.25 \%$ control deep beam

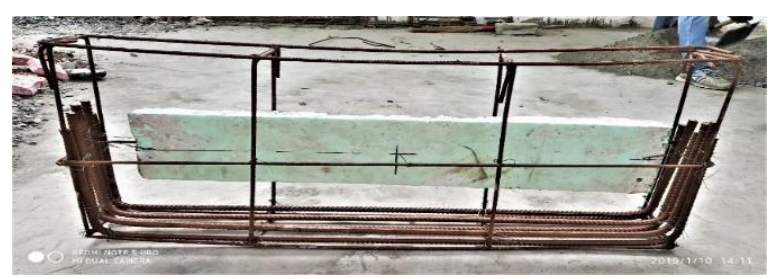

Figure 7. Reinforcement details of $0.25 \%-200 \mathrm{~mm}$ deep beam

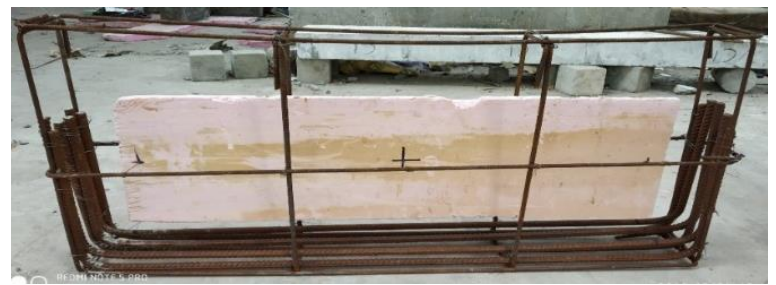

Figure 8. Reinforcement details of $0.25 \%-300 \mathrm{~mm}$ deep beam 


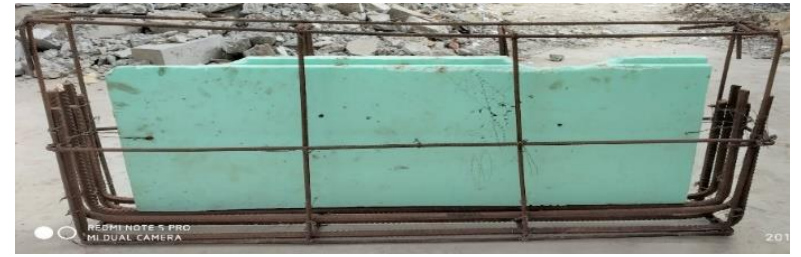

Figure 9. Reinforcement details of $0.25 \%-400 \mathrm{~mm}$ deep beam

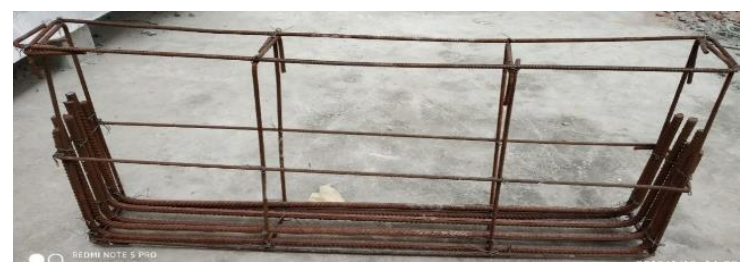

Figure 10. Reinforcement details of $0.35 \%$ control deep beam

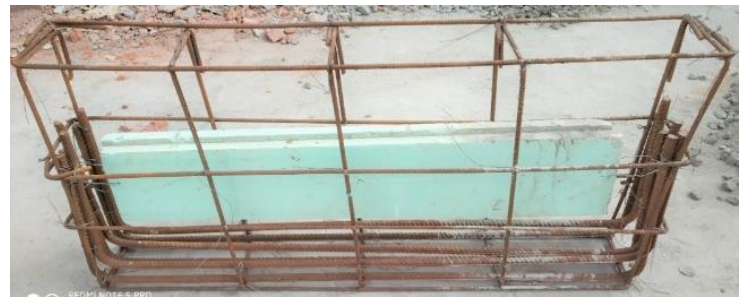

Figure 11. Reinforcement details of $0.35 \%-200 \mathrm{~mm}$ deep beam

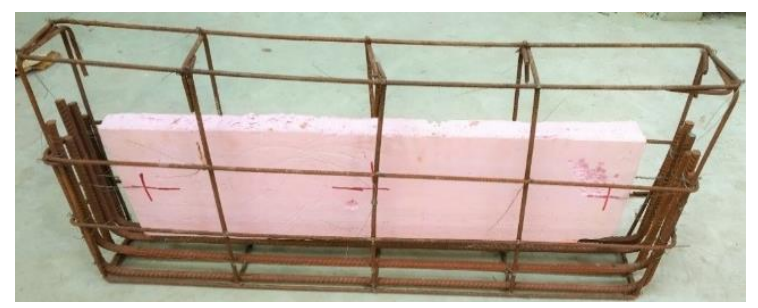

Figure 12. Reinforcement details of 0.35\%-300mm deep beam

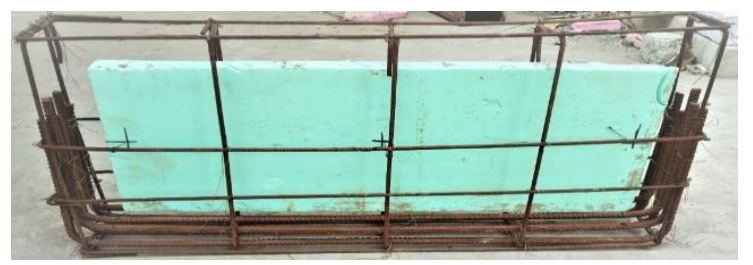

Figure 13. Reinforcement details of $0.35 \%-400 \mathrm{~mm}$ deep beam

\section{RESEARCH SIGNIFICANCE}

This work expects to give experimental evidence on the shear behavior of Reinforced concrete deep beams [11] to allow a superior comprehension of the impacts of fluctuating the depth of the sandwich sheet. The issues will likewise permit an estimation of the present code arrangements and help distinguish their controls.

Note: a/d - shear span to depth ratio, B - width of specimen in $\mathrm{mm}, \mathrm{D}$ - depth of specimen in $\mathrm{mm}, \rho_{-} \mathrm{v}$ and $\rho \_\mathrm{h}$ - percentage of vertical and horizontal web reinforcement [12], Ahst and
Avst- area of vertical and horizontal shear reinforcement in $\mathrm{mm}^{2}$, nh and $\mathrm{nv}$ - number of stirrups in vertical and horizontal, Svands $s_{\mathrm{h}}$ center to center spacing between vertical and horizontal shear reinforcement in $\mathrm{mm}$. All the beams maintain 6 bars of 16mm diameter steel bars @ 95mm from base of the beam in tension zone in two layers c-c distance of $75 \mathrm{~mm}$ and Ast $1206.37 \mathrm{~mm}^{2}$ for all control and sandwich specimens.

\section{SPECIMEN DETAILS}

The test specimens consisted of four simply supported beams (shown in Figure 1) $600 \mathrm{~mm}$ deep and $200 \mathrm{~mm}$ wide and effective span Leff of $1035 \mathrm{~mm}$ the beams had a tension steel area As $=300 \mathrm{~mm}^{2}$, providing $\rho=0.25$ percent. All the beams have the same shear span by depth ratio $(\mathrm{a} / \mathrm{d}=0.875)$ and effective length by depth ratio (Leff/d $=1.725)$ and varies the depth of polystyrene (dp) at different depths of $200 \mathrm{~mm}$, $300 \mathrm{~mm}, 400 \mathrm{~mm}$ of length (Lp) $1000 \mathrm{~mm}$ and width (Wp) of $50 \mathrm{~mm}$ placed at the middle of the cage. At locations of loading or support point, a local reinforcement cage was provided to prevent premature crushing or bearing failure. One variation is introduced, viz., depth of sandwich depth $200 \mathrm{~mm}, 300 \mathrm{~mm}$, $400 \mathrm{~mm}$ and their cross-sections. While the concrete mix design is given in Table 1. The reinforcement details of sandwich deep beam shown in Figure 2 to Figure 13.

\section{STUDY OF DEEP BEAM}

The testing of beam under three-point loading with 2000KN capacity loading. The testing point will be observing the shear behavior of beam with different shear reinforcement percentages respective sandwich depths. All beams were tested under gradually applied loading under 28days curing period. The deflections of the beam observed mid span of the beam by appropriate LVDT. The load at mid span or diagonal points a definitive shear cracks of the deep beam noted.

\section{RESULTS AND DISCUSSION}

\subsection{Modes of failure of $0.15 \%$ sandwich deep beam specimens}

\subsubsection{Deflections}

Figure 14 shows the behavior of the control specimen (DBW0.15) under the initial and ultimate loading condition at $490 \mathrm{kN}$ and $773 \mathrm{kN}$ load. It shows deflection of $1.66 \mathrm{~mm}$ at an initial diagonal crack load of $490 \mathrm{kN}$ and $2.53 \mathrm{~mm}$ at the ultimate diagonal crack load $773 \mathrm{kN}$. Table 3 show the experimental load values. Figure 15 shows the behavior of DB200W0.15 under initial and ultimate loading condition at $359 \mathrm{kN}$ and $639.1 \mathrm{kN}$ load. It shows deflection of $0.915 \mathrm{~mm}$ at the initial diagonal crack load of $359 \mathrm{kN}$ and $2.153 \mathrm{~mm}$ at ultimate diagonal crack load $639.1 \mathrm{kN}$. Figure 16 shows the behavior of DB300W0.15 under initial and ultimate loading condition at $327 \mathrm{kN}$ and $507.1 \mathrm{kN}$ load. It shows deflection of $0.329 \mathrm{~mm}$ at the initial diagonal crack load of $327 \mathrm{kN}$ and 2.01 $\mathrm{mm}$ at ultimate diagonal crack load $507.1 \mathrm{kN}$. Figure 17 shows the behavior of DB400W0.15 under initial and ultimate loading condition at $315 \mathrm{kN}$ and $430 \mathrm{kN}$ load. It shows deflection of $0.3 \mathrm{~mm}$ at an initial diagonal crack load of 315 $\mathrm{kN}$ and $1.35 \mathrm{~mm}$ at ultimate diagonal crack load $507.1 \mathrm{kN}$. Figure 18 shows the shear strength [13] comparison of $0.15 \%$ 
control specimen along with varying insulation pad depths of $200 \mathrm{~mm}, 300 \mathrm{~mm}, 400 \mathrm{~mm}$ specimens shows that 1DBW0.15 specimen gives better results compare other specimens. And DB200W0.15 shear strength [14] results are nearly equal to control specimen remaining will fail at $327 \mathrm{kN}, 315 \mathrm{kN}$. When increasing the depth of core material decreases the shear strength of specimens. Details of specimens are shown in Table 2.

Table 2. Details of specimens

\begin{tabular}{ccccccccccc}
\hline S. No & Beam Designation & $\boldsymbol{\rho}_{\mathbf{s}} \%$ & $\boldsymbol{\rho}_{\mathbf{h}} \boldsymbol{\&} \boldsymbol{\rho}_{\mathbf{v}} \%$ & $\mathbf{A}_{\mathbf{h s t}}$ & $\mathbf{A}_{\mathbf{v s t}}$ & $\mathbf{n}_{\mathbf{s}}$ & $\mathbf{n}_{\mathbf{h}}$ & $\mathbf{n}_{\mathbf{v}}$ & $\mathbf{S}_{\mathbf{v}}$ & $\mathbf{S}_{\mathbf{h}}$ \\
\hline 1 & 1DBW0.15 & 1 & 0.15 & 201.06 & 301.59 & 6 & 4 & 6 & 575 & 550 \\
2 & 1DB200W0.15 & 1 & 0.15 & 201.06 & 301.59 & 6 & 4 & 6 & 575 & 550 \\
3 & 1DB300W0.15 & 1 & 0.15 & 201.06 & 301.59 & 6 & 4 & 6 & 575 & 550 \\
4 & 1DB400W0.15 & 1 & 0.15 & 201.06 & 301.59 & 6 & 4 & 6 & 575 & 550 \\
5 & 2DBW0.25 & 1 & 0.25 & 301.59 & 402.12 & 6 & 6 & 8 & 383.3 & 275 \\
6 & 2DB200W0.25 & 1 & 0.25 & 301.59 & 402.12 & 6 & 6 & 8 & 383.3 & 275 \\
7 & 2DB300W0.25 & 1 & 0.25 & 301.59 & 402.12 & 6 & 6 & 8 & 383.3 & 275 \\
8 & 2DB400W0.25 & 1 & 0.25 & 301.59 & 402.12 & 6 & 6 & 8 & 383.3 & 275 \\
9 & 3DBW0.35 & 1 & 0.35 & 402.12 & 502.65 & 6 & 8 & 10 & 287.5 & 137.5 \\
10 & 3DB200W0.35 & 1 & 0.35 & 402.12 & 502.65 & 6 & 8 & 10 & 287.5 & 137.5 \\
11 & 3DB300W0.35 & 1 & 0.35 & 402.12 & 502.65 & 6 & 8 & 10 & 287.5 & 137.5 \\
12 & 3DB400W0.35 & 1 & 0.35 & 402.12 & 502.65 & 6 & 8 & 10 & 287.5 & 137.5 \\
\hline
\end{tabular}

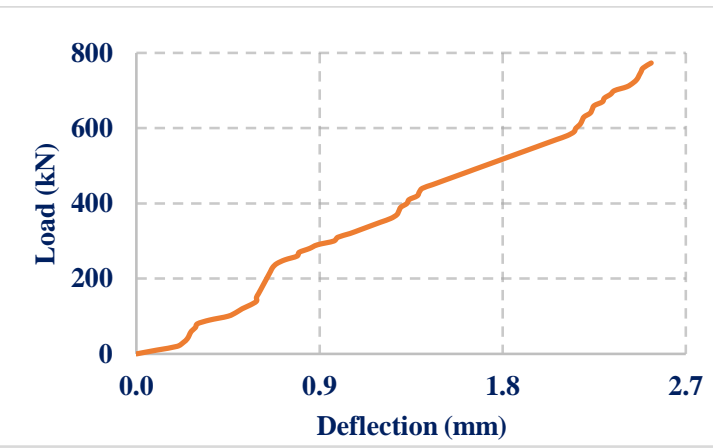

Figure 14. Load vs deflectionof $0.15 \%$ control specimen

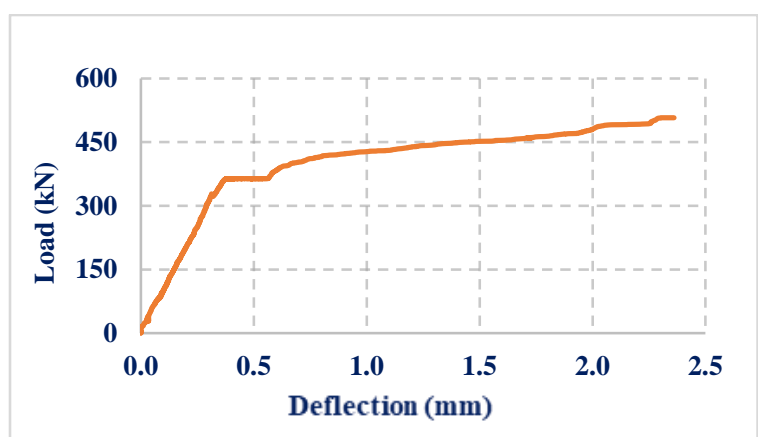

Figure 16. Load vs deflectionof $0.15 \%$ - $300 \mathrm{~mm}$ deep beam

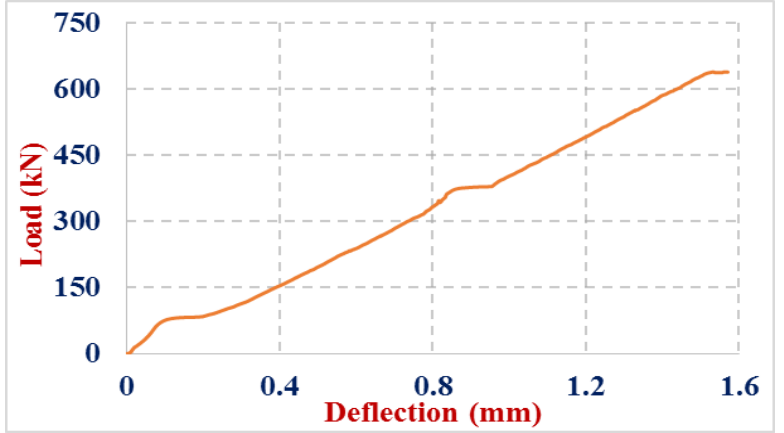

Figure 15. Load vs deflectionof $0.15 \%$ - $200 \mathrm{~mm}$ deep beam

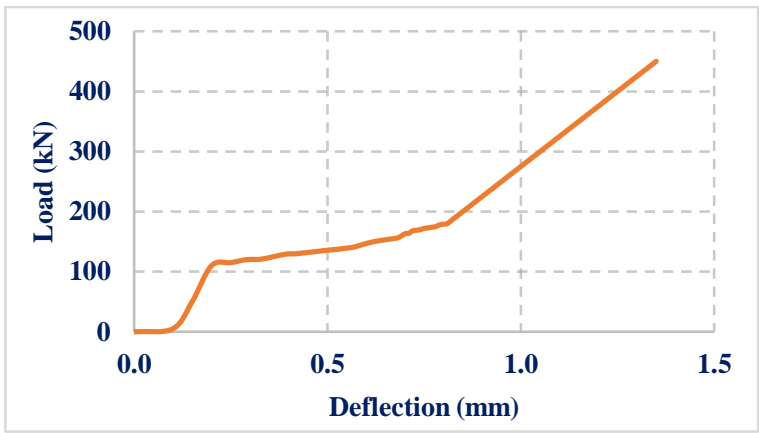

Figure 17. Load vs deflectionof $0.15 \%-400 \mathrm{~mm}$ deep beam

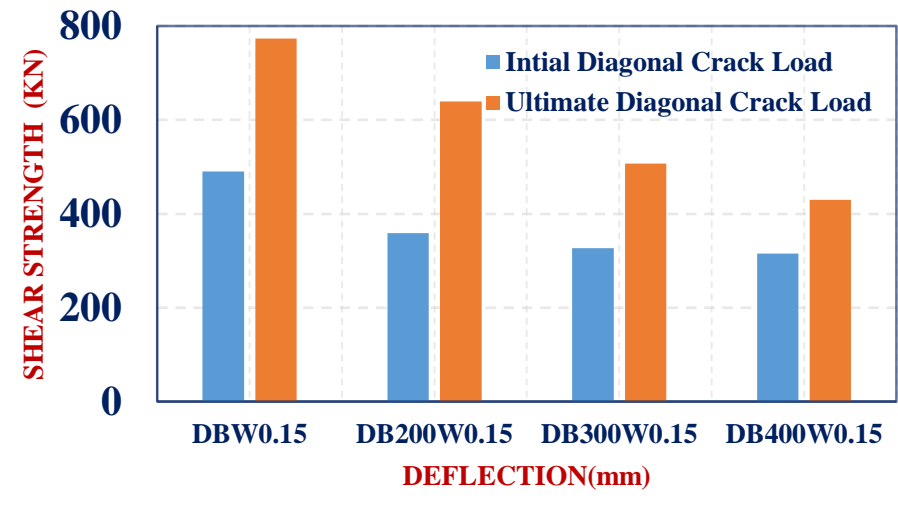

Figure 18. Shear strength comparison of $0.15 \%$ deep beam 
6.1.2 Crack patterns, failure modes and crack widths

Figure 20 shows a crack pattern of $0.15 \% 200 \mathrm{~mm}$ specimen of $0.02 \mathrm{~mm}, 0.03 \mathrm{~mm}$ at initial loading point of $359 \mathrm{kN}$ and $0.2 \mathrm{~mm}, 0.4 \mathrm{~mm}$ crack width at $639.1 \mathrm{kN}$. Figure 21 shows a crack pattern of $0.15 \% 300 \mathrm{~mm}$ specimen of $0.02 \mathrm{~mm}, 0.035$ $\mathrm{mm}$ at initial loading point of $327 \mathrm{kN}$ and $0.2 \mathrm{~mm}, 0.4 \mathrm{~mm}$ crack width at $507 \mathrm{kN}$. Figure 22 shows a crack pattern of $0.15 \% 400 \mathrm{~mm}$ specimen of $0.02 \mathrm{~mm}, 0.03 \mathrm{~mm}$ at initial loading point of $315 \mathrm{kN}$ and $0.2 \mathrm{~mm}, 0.4 \mathrm{~mm}$ crack width at $430 \mathrm{kN}$. Details of experimental data shown in Table 3.

The ultimate load of 1DBW0.15 with initial crack of 1DB200W0.15, 1DB300W0.15, and 1DB400W0.15 specimens $36.60 \%, 46.40 \%, 42.30 \%, 40.75 \%$. That shear strength [15] of 1DB200W0.15 gives better comparative results compare to other specimens of $0.15 \%$ sandwich deep beam group.

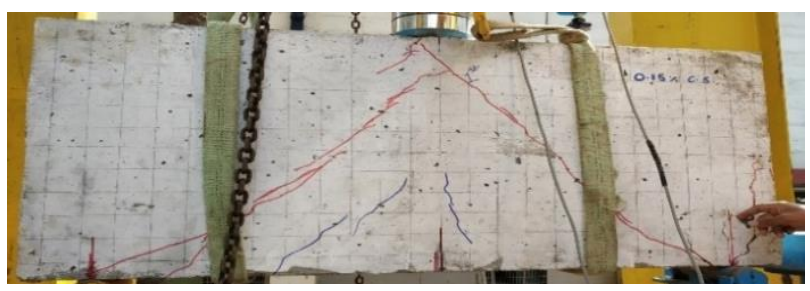

Figure 19. Ultimate loading condition $0.15 \%$ deep beam

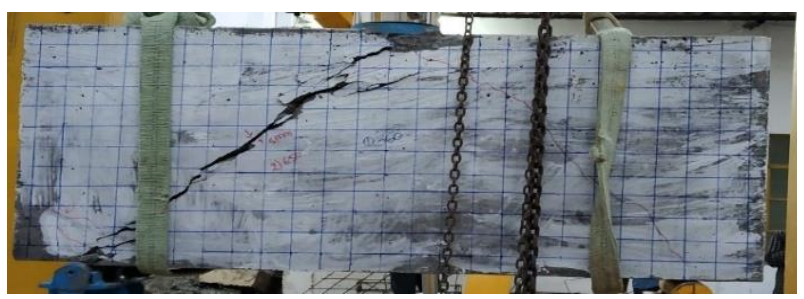

Figure 20. Ultimate loading condition $0.15 \%$ - $200 \mathrm{~mm}$ deep beam

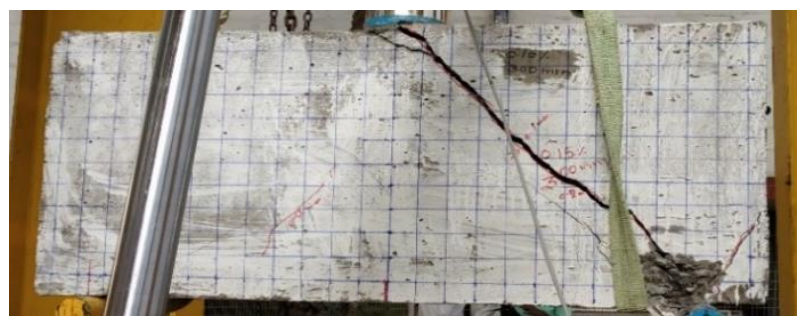

Figure 21. Ultimate loading condition $0.15 \%$ - $300 \mathrm{~mm}$ deep beam

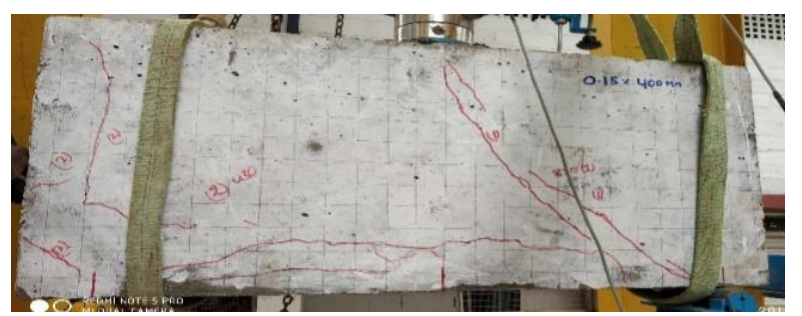

Figure 22. Ultimate loading condition $0.15 \%$ - $400 \mathrm{~mm}$ deep beam

\subsection{Modes of failure of $0.25 \%$ sandwich deep beam specimens}

Figure 23 shows the behaviour of the control specimen
(2DBW0.25) under the initial and ultimate loading condition at $490 \mathrm{kN}$ and $847.8 \mathrm{kN}$ load. It shows deflection of $0.93 \mathrm{~mm}$ at an initial diagonal crack load of $490 \mathrm{kN}$ and $2.22 \mathrm{~mm}$ at the ultimate diagonal crack load $847.8 \mathrm{kN}$. Table 3 show the experimental load values. Figure 24 shows the behaviour of 2DB200W0.25 under initial and ultimate loading condition at $427.9 \mathrm{kN}$ and $805.4 \mathrm{kN}$ load. It shows deflection of $2.67 \mathrm{~mm}$ at the initial diagonal crack load of $805.4 \mathrm{kN}$ and $3.5 \mathrm{~mm}$ at ultimate diagonal crack load $805.4 \mathrm{kN}$. Figure 25 shows the behaviour of 2DB300W0.25 under initial and ultimate loading condition at $409 \mathrm{kN}$ and $727.3 \mathrm{kN}$ load. It shows deflection of $0.356 \mathrm{~mm}$ at the initial diagonal crack load of $409 \mathrm{kN}$ and 2.45 $\mathrm{mm}$ at ultimate diagonal crack load $727.3 \mathrm{kN}$. Figure 26 shows the behaviour of 2DB400W0.25 under initial and ultimate loading condition at $345 \mathrm{kN}$ and $613.3 \mathrm{kN}$ load. It shows deflection of $0.26 \mathrm{~mm}$ at an initial diagonal crack load of 345 $\mathrm{kN}$ and $0.831 \mathrm{~mm}$ at ultimate diagonal crack load $\mathrm{kN}$. Figure 27 shows the shear strength comparison of $0.25 \%$ control specimen along with varying insulation pad depths of $200 \mathrm{~mm}$, $300 \mathrm{~mm}, 400 \mathrm{~mm}$ specimens shows that 2DBW0.25 specimen gives better results compare other specimens. And 2DB200W0.25 shear strength results are nearly equal to control specimen remaining will fail at $427.7 \mathrm{kN}, 490 \mathrm{kN}$. When increasing the depth of core material decreases the shear strength of specimens.

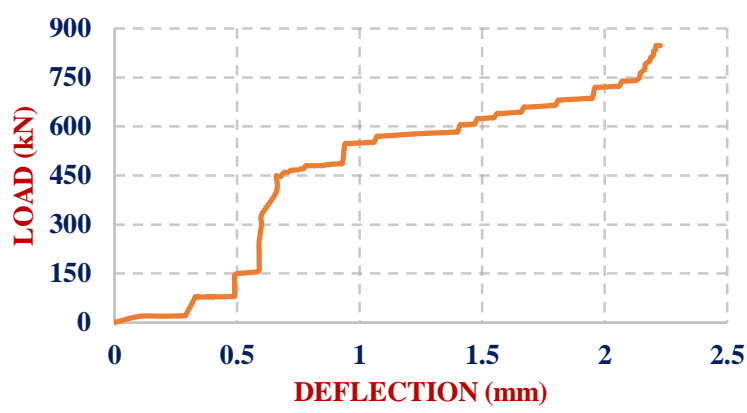

Figure 23. Load vs deflectionof $0.25 \%$ control specimen

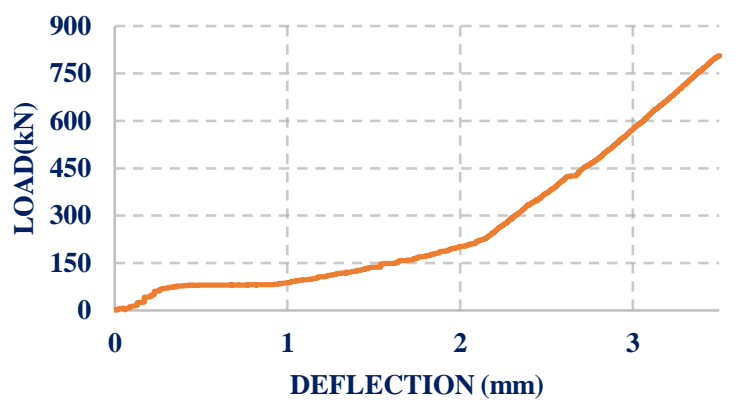

Figure 24. Load vs deflectionof $0.25 \%-200 \mathrm{~mm}$ deep beam

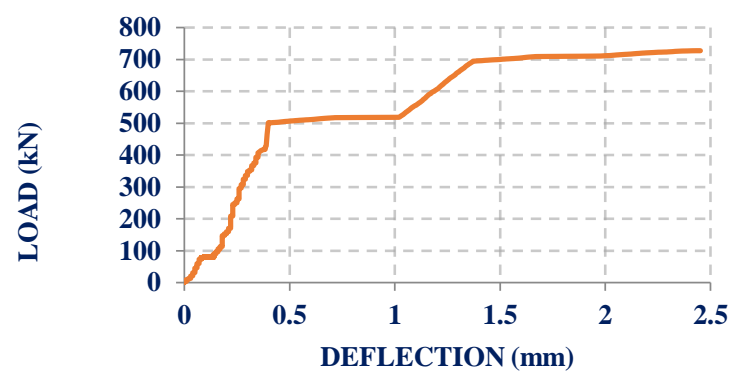

Figure 25. Load vs deflectionof $0.25 \%-300 \mathrm{~mm}$ deep beam 


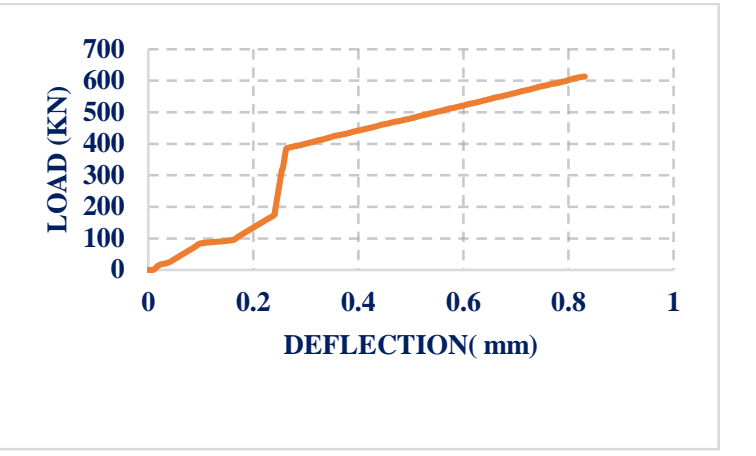

Figure 26. Load vs deflectionof $0.25 \%-400$ deep beam

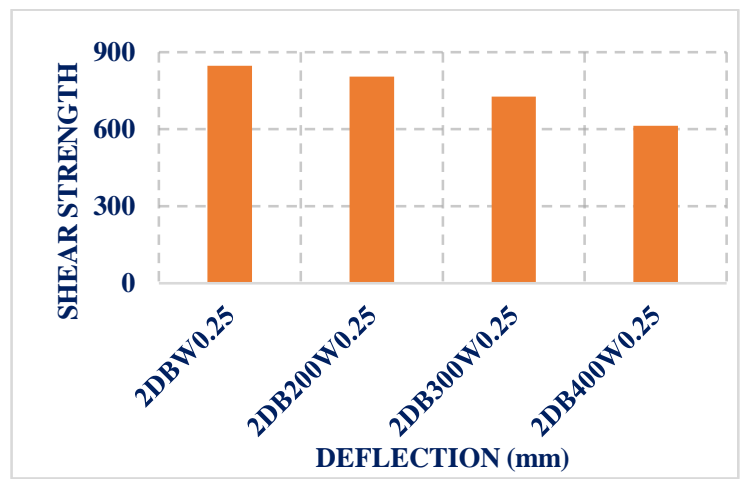

Figure 27. Shear strength comparison of $0.25 \%$ deep beam

\subsubsection{Crack patterns, failure modes and crack widths}

Figure 29 shows a crack pattern of $0.25 \% 200 \mathrm{~mm}$ specimen of $0.01 \mathrm{~mm}, 0.02 \mathrm{~mm}$ at initial loading point of $427.9 \mathrm{kN}$ and $0.1 \mathrm{~mm}, 0.3 \mathrm{~mm}$ crack width at $805.4 \mathrm{kN}$. Figure 30 shows a crack pattern of $0.25 \% 300 \mathrm{~mm}$ specimen of $0.02 \mathrm{~mm}$, $0.03,0.04 \mathrm{~mm}$ at initial loading point of $409 \mathrm{kN}$ and 0.2 $\mathrm{mm}, 0.3 \mathrm{~mm}, 0.4 \mathrm{~mm}$ crack width at $727.3 \mathrm{kN}$. Figure 31 shows a crack pattern of $0.25 \% 400 \mathrm{~mm}$ specimen of $0.03 \mathrm{~mm}, 0.04$ $\mathrm{mm}$ at initial loading point of $345 \mathrm{kN}$ and $0.1 \mathrm{~mm}, 0.3 \mathrm{~mm}$ crack width at $613.3 \mathrm{kN}$.

The ultimate load of 2DBW0.25 with initial crack of 2DB200W0.25, 2DB300W0.25, and 2DB400W0.25 specimens $42.20 \%, 49.52 \%, 51.75 \%$ and $59.30 \%$. That shear strength of 2DB200W0.25 gives better comparative results compare to other specimens of $0.25 \%$ sandwich deep beam group.

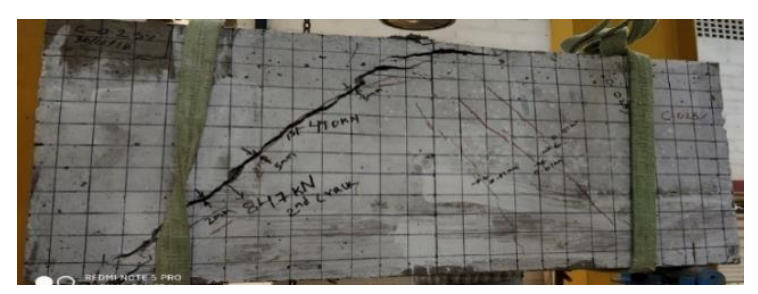

Figure 28. Ultimate loading condition 0.25 deep beam

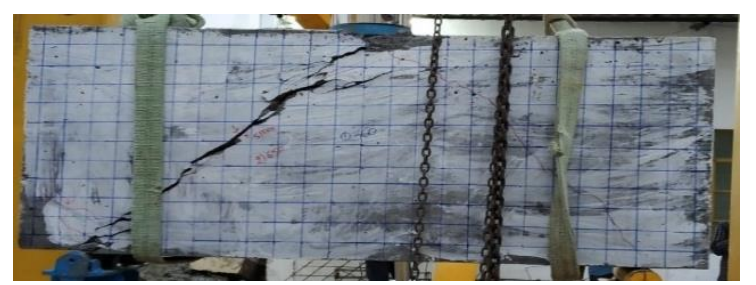

Figure 29. Ultimate loading condition $0.25 \%$ - $200 \mathrm{~mm}$ deep beam

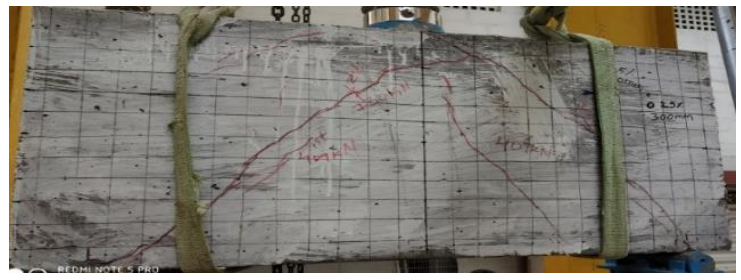

Figure 30. Ultimate loading condition $0.25 \%-300 \mathrm{~mm}$ deep beam

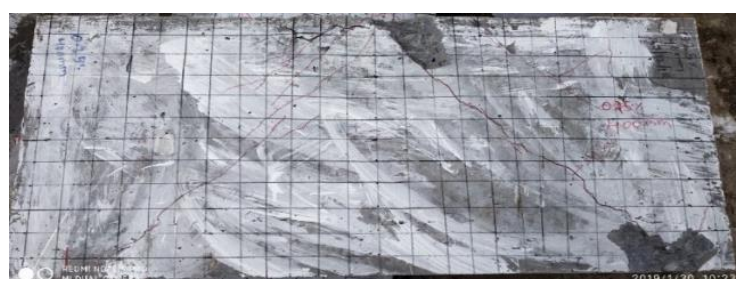

Figure 31. Ultimate loading condition $0.25 \%$ - $400 \mathrm{~mm}$ deep beam

\subsection{Modes of Failure of $0.35 \%$ sandwich deep beam specimens}

Figure 32 shows the behaviour of the control specimen (3DBW0.35) under the initial and ultimate loading condition at $500 \mathrm{kN}$ and $978.4 \mathrm{kN}$ load. It shows deflection of $0.542 \mathrm{~mm}$ at an initial diagonal crack load of $490 \mathrm{kN}$ and $2.42 \mathrm{~mm}$ at the ultimate diagonal crack load $978.4 \mathrm{kN}$. Table 3 show the experimental load values.

Figure 33 shows the behaviour of 3DB200W0.35 under initial and ultimate loading condition at $467.9 \mathrm{kN}$ and 831.6 $\mathrm{kN}$ load. It shows deflection of $1.238 \mathrm{~mm}$ at the initial diagonal crack load of $467.9 \mathrm{kN}$ and $2.22 \mathrm{~mm}$ at ultimate diagonal crack load $831.6 \mathrm{kN}$. Figure 34 shows the behaviour of 3DB300W0.35 under initial and ultimate loading condition at $400 \mathrm{kN}$ and $771 \mathrm{kN}$ load. It shows deflection of $1.485 \mathrm{~mm}$ at the initial diagonal crack load of $400 \mathrm{kN}$ and $2.439 \mathrm{~mm}$ at ultimate diagonal crack load $771 \mathrm{kN}$. Figure 35 shows the behaviour of 3DB400W0.35 under initial and ultimate loading condition at $440 \mathrm{kN}$ and $780 \mathrm{kN}$ load. It shows deflection of $1.77 \mathrm{~mm}$ at an initial diagonal crack load of $440 \mathrm{kN}$ and 2.453 $\mathrm{mm}$ at ultimate diagonal crack load $780 \mathrm{kN}$. Figure 36 shows the shear strength comparison of $0.35 \%$ control specimen along with varying insulation pad depths of $200 \mathrm{~mm}, 300 \mathrm{~mm}$, $400 \mathrm{~mm}$ specimens shows that 3DBW0.35 specimen gives better results compare other specimens. And 3DB200W0.35 shear strength results are nearly equal to control specimen remaining will fail at $500 \mathrm{kN}, 467.9 \mathrm{kN}$ When increasing the depth of core material decreases the shear strength of specimens.

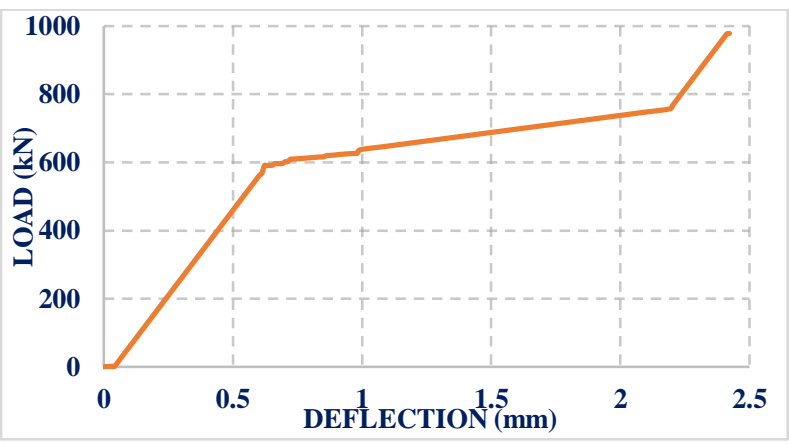

Figure 32. Load vs deflection for $0.35 \%$ control specimen 


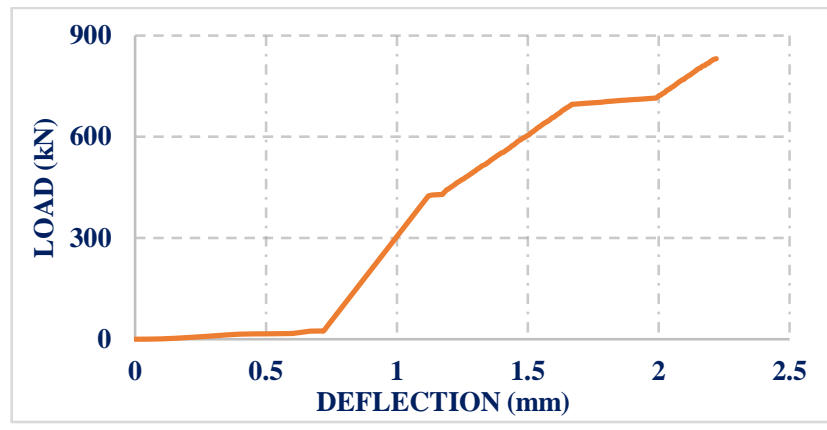

Figure 33. Load vs deflection for $0.35 \%-200 \mathrm{~mm}$ deep beam

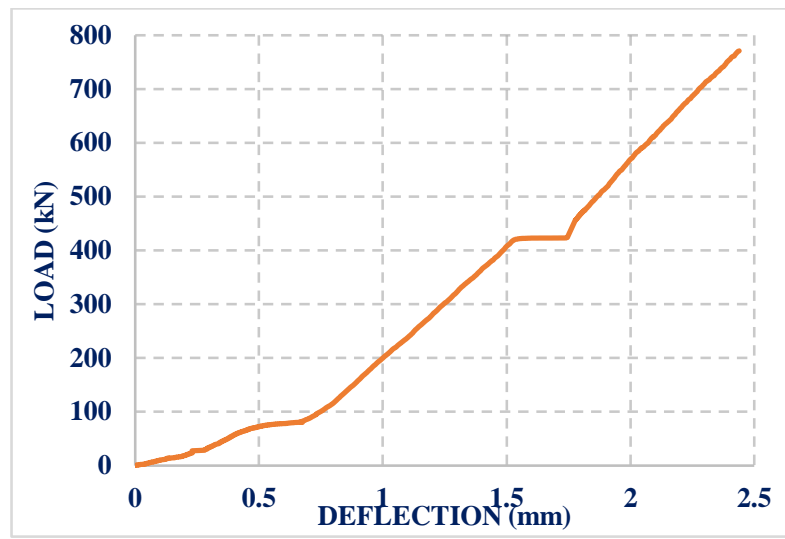

Figure 34. Load vs deflection for $0.35 \%-300 \mathrm{~mm}$ deep beam

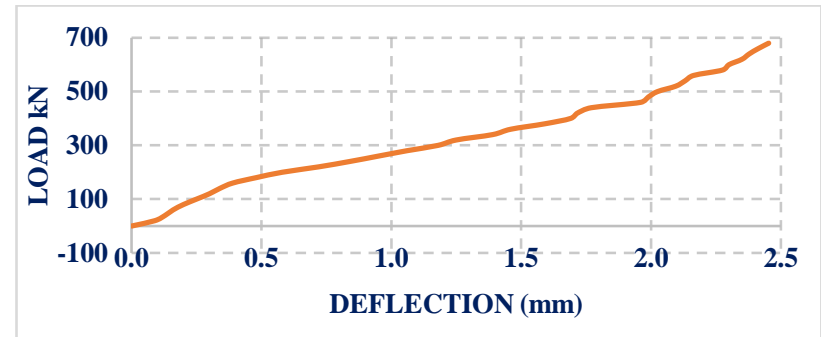

Figure 35. Load vs deflection for $0.35 \%-400 \mathrm{~mm}$ deep beam

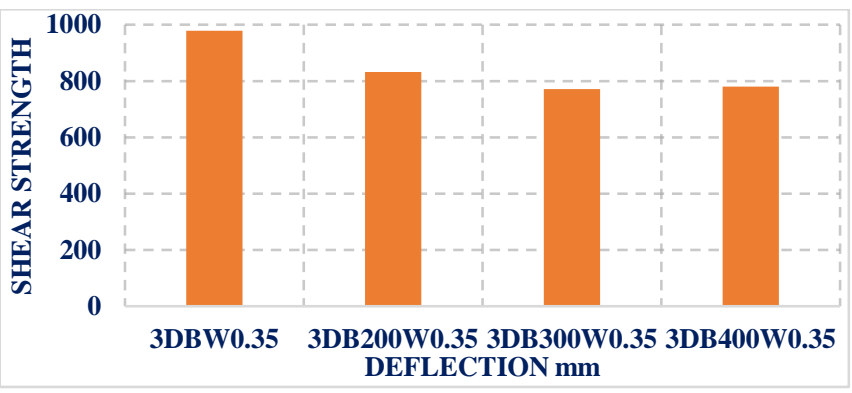

Figure 36. Shear strength comparison of $0.35 \%$ deep beam

6.3.1 Crack patterns, failure modes and crack widths

Figure 38 shows a crack pattern of $0.35 \% 200 \mathrm{~mm}$ specimen of $0.02 \mathrm{~mm}, 0.03 \mathrm{~mm}, 0.05 \mathrm{~mm}$ at initial loading point of 467.9 $\mathrm{kN}$ and $0.1 \mathrm{~mm}, 0.3 \mathrm{~mm}$ crack width at $831.6 \mathrm{kN}$. Figure 39 shows a crack pattern of $0.35 \% 300 \mathrm{~mm}$ specimen of 0.03 $\mathrm{mm}, 0.004 \mathrm{~mm}$ at initial loading point of $400 \mathrm{kN}$ and 0.2 $\mathrm{mm}, 0.3 \mathrm{~mm}, 0.4 \mathrm{~mm}$ crack width at $771 \mathrm{kN}$.Figure 40 shows a crack pattern of $0.35 \% 400 \mathrm{~mm}$ specimen of $0.02 \mathrm{~mm}, 0.04$ $\mathrm{mm}$ at initial loading point of $440 \mathrm{kN}$ and $0.1 \mathrm{~mm}, 0.3 \mathrm{~mm}$ crack width at $780 \mathrm{kN}$.

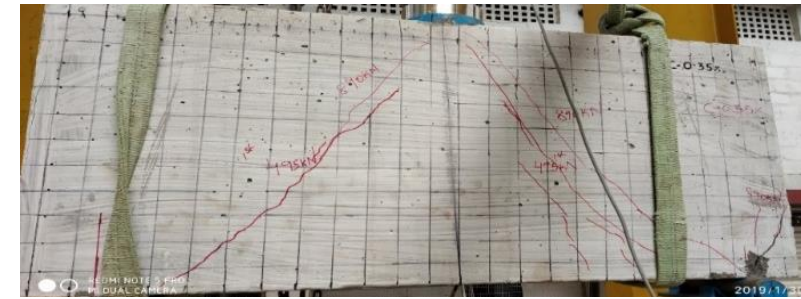

Figure 37. Ultimate loading condition 0.35 deep beam

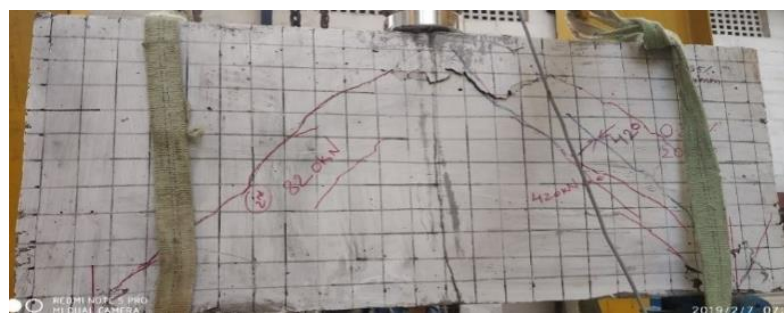

Figure 38. Ultimate loading condition $0.35 \%$ - $200 \mathrm{~mm}$ deep beam

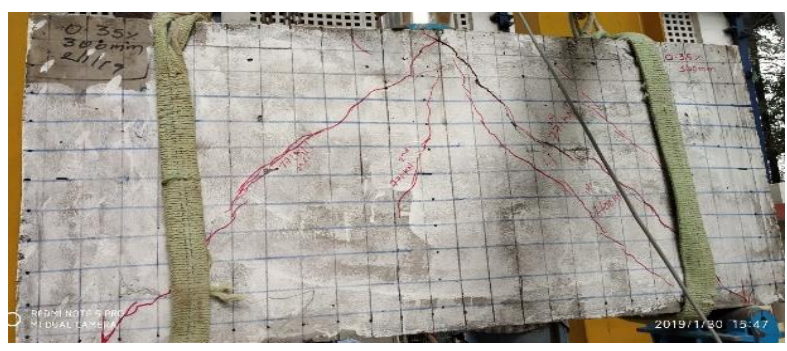

Figure 39. Ultimate loading condition $0.35 \%$ - $300 \mathrm{~mm}$ deep beam

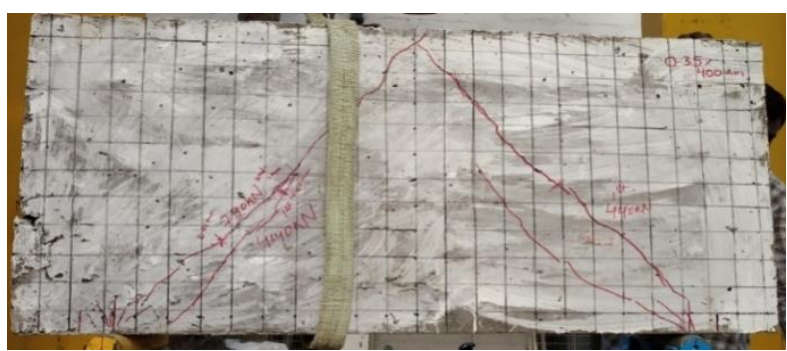

Figure 40. Ultimate loading condition $0.35 \%$ - $400 \mathrm{~mm}$ deep beam

The ultimate shear strength [12] of 3DBW0.35 shows that 3DB200W0.35 has $47.82 \%$, 3DB300W0.35 has $40.8 \%$, and 3DB400W0.35 has $44.97 \%$. In that 3DB200W0.35 had high shear strength influence of $47.82 \%$ and 3DB300W0.35 had low shear strength influence on ultimate shear strength $40.8 \%$ of deep beam. Details of initial crack, ultimate crack of shear strength percentages $(0.15 \%, 0.25 \%$, and $0.35 \%)$ as shown in Table 3.

Figure 41 shows the shear behavior of reinforced concrete $[16,17]$ deep beams with different shear reinforcement percentages of $0.15 \%, 0.25 \%$, and $0.35 \%$ along vertical and horizontal direction of the beam, in that control specimens of 3DBW0.35 shows better results compare to 1DBW0.15 and 2DBW0.25 due to increase in percentage in 3DBW0.35 along web shear reinforcement. And compare the other beams other than control specimens $0.35 \%$ web reinforcement shows better results compare to beams. 
Table 3. Details of experimental data

\begin{tabular}{cccccccc}
\hline Beam Designation & $\mathbf{V}_{\mathbf{d}}$ & $\mathbf{V}_{\mathbf{u}}$ & $\boldsymbol{\Delta}_{\mathbf{i}}$ & $\boldsymbol{\Delta}_{\mathbf{u}}$ & $\mathbf{W}_{\mathbf{i}}$ & $\mathbf{W}_{\mathbf{u}}$ & Mode of Failure \\
\hline DBW0.15 & 490 & 773 & 1.6 & 2.53 & $0.01,0.03$ & $0.1,0.2$ & DSF \\
DB200W0.15 & 359 & 639.1 & 0.915 & 2.15 & $0.02,0.03$ & $0.2,0.4$ & DSF \\
DB300W0.15 & 327 & 507.1 & 0.329 & 2.01 & $0.03,0.05$ & $0.3,0.4$ & DSF \\
DB400W0.15 & 315 & 430 & 0.3 & 1.35 & $0.02,0.03$ & $0.2,0.3$ & DSF \\
2DBW0.25 & 490 & 847.8 & 0.93 & 2.2 & $0.02,0.03$ & $0.2,0.3$ & DSF \\
2DB200W0.25 & 427.9 & 805.4 & 2.67 & 3.5 & $0.01,0.02$ & $0.1,0.3$ & DSF \\
2DB300W0.25 & 409 & 727.3 & 0.356 & 2.45 & $0.02,0.03,0.04$ & $0.2,0.3,0.4$ & DSF \\
2DB400W0.25 & 345 & 613.3 & 0.26 & 0.83 & $0.03,0.04$ & $0.1,0.3$ & DSF \\
3DBW0.35 & 500 & 978.4 & 0.542 & 2.42 & $0.01,0.03$ & $0.2,0.3$ & DSF \\
3DB200W0.35 & 467.9 & 831.6 & 1.238 & 2.22 & $0.02,0.03,0.05$ & $0.1,0.3$ & DSF \\
3DB300W0.35 & 400 & 771 & 1.485 & 2.43 & $0.03,0004$ & $0.2,0.3,0.4$ & DSF \\
3DB400W0.35 & 440 & 780 & 1.77 & 2.45 & $0.02,0.04$ & $0.1,0.3$ & DSF
\end{tabular}

Note: Vd states that initial diagonal crack load in $\mathrm{kN}, \mathrm{Vu}$ states that ultimate diagonal crack load in $\mathrm{kN}, \Delta \mathrm{i}$ states that initial deflection in $\mathrm{mm}, \Delta \mathrm{u}$ states that final deflection $\mathrm{mm}$, Wi states that initial crack load crack width in $\mathrm{mm}$, Wu states that ultimate load crack width in $\mathrm{mm}$, and DSF states that diagonal shear failure of deep beam.

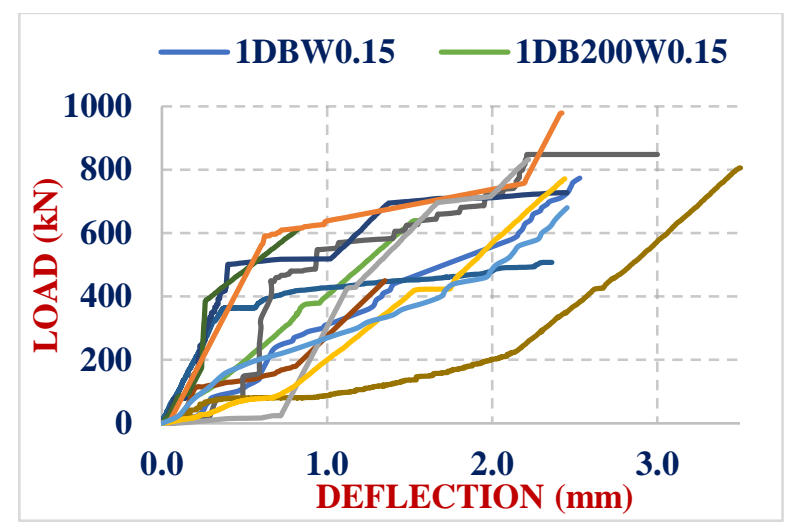

Figure 41. Load vs Deflection comparison of $0.15 \%, 0.25 \%$, and $0.35 \%$ reinforcement deep beams

\section{CONCLUSION}

The present study displays the discoveries of an experimental program concocted to research the variation of insulation pad depths in the centre of the deep beams. The width of a deep beam is unimportant on shear conduct for $\mathrm{a} / \mathrm{d}$ proportion 0.95 . At the initial and ultimate stage ofloading diagonal crack dominates the flexural crack:

1) All the four examples show corner to corner break as it were.

2) Cracks keep up more prominent than $25^{\circ}$ from loading point as appeared in Figure 19-Figure 22, Figure 28Figure 31, and Figure 37-Figure 40.

3) 1DB400W0.15 show breaks at sides with a width of 0.05 $\mathrm{mm}, 0.06 \mathrm{~mm}$ and $0.07 \mathrm{~mm}$ because of increment of center core depth of insulation pads. And 1DB400W0.25, 1DB400W0.35 won't show these types of failures due to percentage increase of shear reinforcement in both vertical and horizontal direction.

4) Kern segment of the sandwich deep beams of 1DB200W0.15, 1DB200W0.25, and 1DB200W0.35 show's better outcomes compare with other testing specimens.

5) If the depth of the core material exceeds the kern portion, it will show uncertainty result.

6) Increasing the percentage of shear reinforcement also influence on shear strength of deep beam.

7) Depth of insulation pad also influence on shear strength of deep beam.

\section{REFERENCES}

[1] Zhang, N., Tan, K.H. (2007). Size effect in RC deep beams: Experimental investigation and STM verification. Engineering Structures, 29(12): 3241-3254. https://doi.org/10.1016/j.engstruct.2007.10.005

[2] Rao, G.A., Sundaresan, R. (2012). Evaluation of size effect on shear strength of reinforced concrete deep beams using refined strut-and-tie model. Sadhana, 37(1): 89-105. https://doi.org/10.1007/s12046-012-0068-2

[3] Karihaloo, B.L. (1995). Fracture mechanics \& structural concrete. Longman Scientific and Technical Publishers, John Wiley, USA. https://doi.org/10.1007/bf00035376

[4] Daniel, I.M., Gdoutos, E.E. (2009). Failure modes of composite sandwich beams. Major Accomplishments in Composite Materials and Sandwich Structures, Springer, Dordrecht. https://doi.org/10.1007/978-90-481-31419_9

[5] Rao, G.A., Sundaresan, R. (2014). Size dependent shear strength of reinforced concrete deep beams based on refined strut-and-tie model. Advanced Materials Research, 931-932: 468-472. https://doi.org/10.4028/www.scientific.net/AMR.931932.468

[6] Tan, K.H., Cheng, G.H., Zhang, N. (2008). Experiment to mitigate size effect on deep beams. Magazine of $\begin{array}{lll}\text { Concrete } \quad \text { Research, } & 60(10) \text { : }\end{array}$ https://doi.org/10.1680/macr.2007.00030

[7] Oh, J.K., Shin, S.W. (2001). Shear strength of reinforced high-strength concrete deep beams. Structural Journal, 98(2): 164-173. https://doi.org/10.14359/10184

[8] IS: 456 - 2000, Code of practice for Plain and Reinforced Concrete, Bureau of Indian Standards, New Delhi, India. https://doi.org/10.14359/15584

[9] David, B.B., Tuchscherer, R.G., Huizinga, M., Bayrak, O. (2014). Minimum web reinforcement in deep beams. ACI Structural Journal, 111(1): 224-225. https://doi.org/10.14359/51684409

[10] Tan, K.H., Kong, F.K., Teng, S., Guan, L. (1995). Highstrength concrete deep beams with effective span and shear span variations. Structural Journal, 92(4): 395-405. https://doi.org/10.14359/991

[11] Birrcher, D.B., Tuchscherer, R.G., Huizinga, M., Bayrak, O. (2013). Minimum web reinforcement in deep beams. ACI Structural Journal, 110(2). https://doi.org/10.14359/51684409 
[12] Albidah, A., Abadel, A., Abbas, H., Almusallam, T., AlSalloum, Y. (2019). Experimental and analytical study of strengthening schemes for shear deficient RC deep beams. Construction and Building Materials, 216: 673686. https://doi.org/10.1016/j.conbuildmat.2019.05.024

[13] Duthinh, D. (2000). Shear strength of high-strength concrete walls and deep beams. No. NIST Interagency/Internal Report (NISTIR)-6495. https://doi.org/10.6028/nist.ir.6495

[14] Leon, R.J., Rao, G.A. (2013). Performance of RC deep beams with different combinations of web reinforcement. Applied Mechanics and Materials, 343: 21-26. https://doi.org/10.4028/www.scientific.net/AMM.343.2
1

[15] CSA Committee A23.3, Design of Concrete Structures: Structures, Canadian Standards Association. https://doi.org/10.3403/00785263u

[16] ACI Committee 318. Building Code Requirements for Structural Concrete (ACI 318-08) (318R-08) and Commentary. American Concrete Institute, Farmington Hills, MI, 2008, p. 465. https://doi.org/10.1201/9781420007657.ch36

[17] ACI Committee 318. Building Code Requirement of Reinforced Concrete. Farmington Hills, MI: American ConcreteInstitute, 2014. https://doi.org/10.2749/101686612x13291382990967 